\title{
Cholinesterase and microbial inhibitory activities of Tetrapleura tetraptera
}

\author{
N. E. Okoronkwo ${ }^{1 *}$ and J . O. E cheme ${ }^{2}$ \\ ${ }^{1}$ Department of Pure and Industrial Chemistry, Abia State University Uturu, NIGERIA \\ ${ }^{2}$ Department of Chemistry, Michael Okpara University of Agriculture, Umudike, Abia State, NIGERIA \\ *Corresponding author. E-mail: nnennaejijeokoronkwo@yahoo.com. \\ Received: February 4, 2012; Revised received:J une 3, 2012; Accepted:J uly 1, 2012
}

Abstract: The cholinesterase and microbial inhibitory activities of different parts of Tetrapleura tetraptera plant were evaluated due to their local applications. The cholinesterase results revealed that the extracts showed some levels of inhibitory effects depending on the solvents used. Tetrapleura tetraptera leaves had better inhibitory effects with maximum inhibitory activity of $70.0 \%$ at a concentration of $1.00 \mathrm{mg} / \mathrm{l}$ for the water extract. Tetrapleura tetraptera bark showed highest inhibitory effect of $71.05 \%$ and $(84.34 \%)$ for the ethanol and chloroform extracts at concentrations of $0.5 \mathrm{mg} / \mathrm{l}$ and $1.0 \mathrm{mg} / \mathrm{l}$ respectively. While for petroleum ether, T. tetraptera bark recorded $74.34 \%$ inhibitory effect at concentration of $2.0 \mathrm{mg} / \mathrm{l}$ and also showed continuous increase in inhibitory activity as the concentration increases for aqueous methanol. The results of the antimicrobial activities showed that among all the test organisms, the ethanol and water extracts of the leaves, stem, bark and root of the plants had promising activity against Escherichia coli, Staphylococcus aureus, Proteus mirabilis, Pseudomonas aeruginosa and Klebsiella pneumonia bacteria and Aspergillus fumigatus and R hizopus species fungi. There was no activity shown by the ethanol and water extracts of the parts of the plants with Fugarium oxysporum, Penicillium chrysogenum and Mucor species fungi. The bacteria strains were more sensitive to the tested extracts than the fungi strains.

Keywords: Anticholinesterase, Antimicrobial, Inhibition, Tetrapleura tetraptera

\section{INTRODUCTION}

Tetrapleura tetraptera (Fabaceae Family) is a medium sized deciduous tree with fern-like foliage and highly characteristic fruits. It is a perennial tree which grows along the Western Coast of Africa. The plant's common names are: Aiden (English), İshĺhÍ (Oshoho), Aridan (Yoruba), Ighimiaka (Bini) and Edeminnangi (Efik). In Nigeria, it is used for numerous purposes (Adewunmi et al., 1993). The tree reaches up to $4 \mathrm{mhigh}$ and $1.5-3 \mathrm{~min}$ girth. In the forest, the crown is fairly small, thin and rounded, becoming flat when old, but it tends to spread when in the open. The bark is fairly smooth, grey brown, very thin, slash reddish strong smelling and fairly thick; twigs and young foliage virtually glabrous or minutely hairy (Irvin, 1961 and Oliver-Bever, 1986). The leaves are sessile, glabrous or minutely hairy with common stalk 15 $-30 \mathrm{~cm}$ long, slightly channeled on the upper surface. The pinnate are in mostly 5-9 pinnae, 5-10 cm long, mostly opposite but sometimes alternate, 6-12 leaflet on each side of the pinna-stalk always alternate, 12-25 mm long, 6 $-12 \mathrm{~mm}$ broad, slightly elongated elliptic or slightly obovate, rounded at both ends, the apex sometimes slightly notched, the base usually unequal, practically glabrous, with slender stalks about $2 \mathrm{~mm}$ long.

The flowers are pinkish-cream turning to orange and are densely crowded in spike racemes $5-12 \mathrm{~cm}$ long, usually in pairs in the upper leaf axes. The fruit is persistently hanging at the end of branches on stout stalks, $15-25 \mathrm{~mm}$ long by about $5 \mathrm{~cm}$ across the wing-like ribs; dark purplebrown, glabrous and glossy, usually slightly curved. Two of the wings are hard and woody and the other two filled with a soft sugary pulp. The seeds are hard, black, flat, oval, about $8 \mathrm{~mm}$ long, embedded in the body of the pod which does not split. The wood is reddish to brown heart wood, fairly hard, sapwood white (Keay and Onochie, 1964).

The powdered fruit is used as fish poison and in ointment for the treatment of skin diseases (Bode et al., 1996). The intensive odour produced when the fruit is roasted is claimed to repel insects and snakes (Nwaiwu and Aka, 1986). The methanol extract of the fruit which was linked to their saponin content has been reported to have molluscidal property and its mechanism of action is by ultrastructural effects of the snail digestive system (Adesina et al., 1980 and Bode et al., 1996). The leaves, bark, roots, fruits and kernels are used for medicinal purposes (Adesina 1982; Nwaiwu and Aka, 1986 and Okochi, et al., 1999). Tetrapluera tetraptera is used for the treatment of skin diseases, stem bark extract for the treatment of gonorrhea (Okochi et al., 1999). The plant is used in West Africa to flavor soups and taken as general tonics and stimulant or as part of postpartum diet therapy (Okwu and Ekeke, 2003). 
The plant used for the present study was selected on the basis of the claims of their local use that suggest pesticidal and antimicrobial activities among other local uses. Therefore, this study evaluated the cholinesterase and microbial inhibitory activities of the plant $T$. tetraptera.

\section{MATERIALS AND METHODS}

T. tetraptera plant (leaves and bark) was collected from Umuohi Atta Autonomous Community, Ikeduru Local Government Area of Imo State and root from Umuntu Olokoro Umuahia South Local Government Area of Abia State, Nigeria. The plant was identified by Mr Ibe Ndukwe of the Forestry Department, Michael Okpara University of Agriculture, Umudike, Abia State.

Preparation and preservation of samples: The parts of the plants samples collected were separated from each other. The leaves of the plants were separated from their stem and some with flowers were left with the stem. The stem, bark and root of T. tetraptera were further reduced with sharp knife into smaller parts to facilitate drying. These samples were air-dried at room temperature. The air-dried samples were pulverized into powdery form using a brand new corona landers manual milling machine. The samples were stored in labelled polyethene bags.

Extraction of sample for cholinesterase activity: The extraction method used in this study was a modification of JohnBull and Afolabi (2001), JohnBull et al. (2001) and JohnBull and Abdu (2006a and b). $750 \mathrm{~g}$ to $1 \mathrm{~kg}$ of each of the pulverized samples were soaked in different glass bottles to obtain the ethanol (crude) extract individually by percolating in about 2.5 litres of ethanol (98\% analytical standard) for 72hours, followed by filteration and then concentrated under reduced pressure rotary evaporator at $34^{\circ} \mathrm{C}$ separately. These were then allowed to stand for complete evaporation of the remaining ethanol at room temperature. The crude ethanol extracts were stored in labelled covered beakers for further analyses

Partitioning of the cr ude ethanol extract: $15-20 \mathrm{~g}$ of each of the crude ethanol extract of the sample was partitioned using $150 \mathrm{ml} / 150 \mathrm{ml} \mathrm{v} / \mathrm{v}$ of chloroform and water. The sample was first dissolved using the solvents. They were continuously stirred to ensure complete dissolution and were then transferred into different separating funnels which were shaken until homogenous mixtures were obtained. They were then allowed to stand for $24 \mathrm{hrs}$ before separating. The chloroform extracts were allowed to evaporate completely under room temperature. These procedures were repeated for aqueous methanol/ petroleum ether using equal volumes of aqueous methanol petroleum ether (40 - 60) using part of the chloroform extracts. The water fractions were stored in a refrigerator while other fractions were allowed to dry under room temperature.

C holinester aseassay (E nzyme assay technique, EAT):

The determination of an enzyme is based upon the rate of utilization of substrate or formation of product under controlled conditions. Most enzyme assays are carried out at $30^{\circ} \mathrm{C}$ but some are performed at $37^{\circ} \mathrm{C}$ because of the physiological significance of the temperature.The changes in absorbance can be used as basis of the assay. Appropriate amounts of crude ethanol and partitioned fractions $(5,10,20 \mu \mathrm{g})$ were prepared in acetone. Fresh sheep liver was prepared from healthy sheep which was stored in the ice-chamber immediately after slaughter, which was executed under five minutes.

Cholinesterase inhibition by colorimetric method was adopted but with the following modifications; appropriate amounts of the test samples 5,10,20 $\mu \mathrm{g}$ were measure and $0.1 \mathrm{ml}$ of acetone were separately dispensed into the test tubes and the solvent acetone was allowed to evaporate. Then $0.1 \mathrm{ml}$ of $1 \%$ sheep liver homogenate was preincubated with 5,10,20 $\mu \mathrm{g}$ of the test compounds, separately for 15 minutes at $37^{\circ} \mathrm{C}$ in a thermostatic water bath. Standard Huperzine A was also preincubated in the same manner described above with $0.1 \mathrm{ml}$ of $1 \%(\mathrm{w} / \mathrm{v})$ to allow the inhibition of liver cholinesterase by test compounds. After pre-incubation, $0.2 \mathrm{ml}$ of $0.2 \%$ green azo dye in water was added followed by $0.1 \mathrm{ml}$ of $0.01 \mathrm{M}$ ethyl acetate substrate in acetone and the reaction mixture was again incubated for one minute for enzymatic reaction. The reaction mixture was made up to a total of $1.0 \mathrm{ml}$ with distilled water prior to addition of substrate. Caution was taken to see that the enzymatic incubation time of one minute after addition of substrate did not exceed. The enzyme activity was stopped at the end of exactly one minute by adding $4 \mathrm{ml}$ of glacial acetic acid. The colour developed was taken at $620 \mathrm{~nm}$ in a spectrophotometer.

The control enzyme reaction mixtures were without the test compounds and control reaction mixture was also made up to a total of $1 \mathrm{ml}$ with distilled water. However, the preincubation of 15 minutes with enzyme alone and enzymatic incubation for 1 minute with addition of ethylacetate substrate and green azo dye was carried out without adding the test compounds. The control optical density was normalized to $100 \%$ and the percent inhibition was calculated as

$$
\frac{C-E}{C} \times 100=\% \text { inhibition }
$$

where $\mathrm{C}=$ Control absorbance unit, $\mathrm{E}=$ Experimental absorbance unit (with test compounds).

From enzymatic activity units

$$
\frac{C-E}{C} \times 100=\% \text { ChE inhibition }
$$

where $\mathrm{C}=$ Amount of ethanol formed in Control, $\mathrm{E}=$ Amount of ethanol formed in Experimental. 


\section{Antimicrobial activity test:}

Preparation of plant extracts: The ethanol and water extracts of the plant samples were prepared by cold percolation method. $20 \mathrm{~g}$ of each of the pulverized samples was soaked in different $200 \mathrm{ml}$ of ethanol and water respectively for $48 \mathrm{hrs}$ for optimum extraction with intermittent shaking to get a concentration of $10 \%$, after which they were filtered with Whatman paper No. 1 into vials. The filtrate of each extract was dried until a constant dry weight of each extract was obtained. The extracts were stored at $4^{\circ} \mathrm{C}$ for further use.

Preparation of culture media: Nutrient agar was used as medium in the antibacterial assy. The milky white powder has the formulation $5.0 \mathrm{~g} / \mathrm{l}$ peptone, $12.0 \mathrm{~g} / \mathrm{l}$ agar, $8.0 \mathrm{~g} / 1$ sodium chloride and $3.0 \mathrm{~g} / \mathrm{l}$ beef extract. This was prepared by dissolving $28 \mathrm{~g}$ of nutrient agar powder in $800 \mathrm{ml}$ of distilled water in a calibrated, covered glass bottle and shaken properly. The solution was allowed to stand for 10 minutes, swirled to mix in order to achieve total dissolution of the powder. The dissolved solution was then placed in an autoclave for sterilization at $121^{\circ} \mathrm{C}$ for 15 minutes after which it was allowed to cool to $47^{\circ} \mathrm{C}$ and mixed well before pouring into plates.

Sabauroud Dextrose Agar (SDA) was used as medium in the antifungal assay. The milky white powder contains $10.0 \mathrm{~g} / \mathrm{l}$ balanced peptone No. $1,140.0 \mathrm{~g} / \mathrm{l}$ dextrose and $12.0 \mathrm{~g} / \mathrm{l}$ agar No 2. $62 \mathrm{~g}$ of SDA was dispersed 1 litre of deionized water and was soaked for 10 minutes. The solution was swirled to mix properly and was sterilized by autoclaving at $121^{\circ} \mathrm{C}$ for 15 minutes without allowing the medium to over-heat. The sterilized medium was cooled to $47^{\circ} \mathrm{C}$ and two vials of an antibiotic Ampicilin powder was added, shaken to mix well and allowed to stand for 10 minutes. This was added to increase selectivity.

Preparation of innoculums: Stock cultures were maintained at $4^{\circ} \mathrm{C}$ on slopes of nutrient agar. Active cultures for experiments were prepared by transferring a loopful of cells from the stock cultures to test tubes of nutrient agar broth (NAB) for bacteria and the Sabouraud dextrose broth (SDA) for fungi were incubated without agitation for 24 hours at $37^{\circ} \mathrm{C}$ and $25^{\circ} \mathrm{C}$ respectively. The cultures were diluted with fresh nutrient and Sabouraud dextrose broth to achieve optical density corresponding to $2.0 \times 10^{6}$ colony forming units (CFU/ml) for bacteria and $2.0 \times 10^{6} \mathrm{spore} / \mathrm{ml}$ for fungal strains.

Anti-microbial activity screening: The ethanol and water extracts of the samples were screened against a total of five bacterial strain and five fungi strains. The test organisms were Staphylococcus aureus, Proteus mirabilis, Klebsiella pneumonia, Pseudomonas aeruginosa and $\mathrm{E}$. coli (bacteria) F ugarium oxysporum, Aspergillus fumigatus, Pennicillium chrysogenum, Mucor species and Rhizoprs species (fungi) which were all obtained from the stock culture of the microbiology Lab of Federal Medical Center, Umuahia. Abia State Nigeria.

The antimicrobial activity screening was performed by filter paper disc method (Valsaraji, et al, 1997). In vitro anti-microbial activity was screened by using nutrient agar and Sabouraud dextrose agar for bacteria and fungi respectively. The plates were prepared by pouring $15 \mathrm{ml}$ of molten media into sterile Petri plates. The plates were allowed to solidify for 5 minutes and $0.1 \%$ inoculums suspension was swabbed uniformly and the inoculum was allowed to dry for 5 minutes. About $5 \mathrm{mg}$ of the extract was loaded on $4 \mathrm{~mm}$ sterile disc. The loaded disc was placed on the surface of medium and the extract was allowed to diffuse for 5 minutes and the plates were kept for incubation for 24 hours at $37^{\circ} \mathrm{C}$ and $27^{\circ} \mathrm{C}$ for bacteria and fungi respectively. At the end of incubation, inhibition zones formed around the disc were measured with transparent ruler in millimeter. The experiment was repeated two more times for reaffirmation.

Anti-microbial activity assay: The plates were prepared and inoculated in the screening test $0.1 \mathrm{~g}$ of dried ethanol and water extract were respectively dissolved in $1 \mathrm{ml}$ of ethanol and $1 \mathrm{ml}$ of water to get concentrations of $0.1 \mathrm{~g} /$ $\mathrm{ml}$. Standard solution containing $0.1 \mathrm{~g} / \mathrm{ml}$ ciprofuxacin and $0.1 \mathrm{~g} / \mathrm{ml}$ benomyl were also prepared. About $0.2 \mathrm{ml}$ plant extract, ethanol and water, standard ciprofuxacin and standard benomyl respectively were loaded on separate $4 \mathrm{~mm}$ sterile disc with ethanol and water respectively served as controls for ethanol and water extracts.

Standard ciprofuxacin and standard benomyl discs were used to compare the efficacies of the antibacterial and antifungal activities of the extracts respectively. A loaded disc was placed on the surface of inoculated medium and the substance allowed to diffuse for 5 minutes and plates were kept for incubation for 24 hours at $37^{\circ} \mathrm{C}$ and $27^{\circ} \mathrm{C}$ for bacteria and fungi respectively. At the end of incubation, inhibition zones formed around the discs were measured with transparent ruler in millimeter. The study was performed in triplicate and the mean value was recorded.

The percentage inhibition relative to standard antimicrobial agent was calculated as follows:

$$
\% \text { inhibition }=\frac{\mathrm{Xe}-\mathrm{X} c}{\mathrm{x}_{\mathrm{g}}} \times \frac{100}{1}
$$

where $\mathrm{Xs}=$ inhibition of standard, $\mathrm{Xc}=$ inhibition of control and $\mathrm{Xe}=$ inhibition of extract.

\section{RESULTS AND DISCUSSION}

Cholinesterase inhibition activities: The extracts of T. tetraptera leaves (TTL), bark (TTB) and root (TTR) assessed for their acetyl cholinesterase inhibitory activities revealed that all the extracts showed some levels 
of inhibitory effects depending on the solvents used. The dose dependent inhibitory effects of the different plants extracts using different solvents are shown in Figs. 1-5. For the water extract (Fig. 1), TTL had better inhibitory effect with maximum inhibitory activity of $70.0 \%$ at a concentration of $1.00 \mathrm{mg} / \mathrm{l}$ followed by TTR with $63.68 \%$ inhibitory effect at the same concentration while TTB had maximum inhibitory effect at the concentration of 0.5 $\mathrm{mg} / \mathrm{l}$.

Fig. 2 showed dose dependent inhibitory effect of the ethanol extracts (crude extracts) of the all the parts of the plants on the acetyl cholinesterase; all of them showed maximum inhibitory effects at $0.5 \mathrm{mg} / 1$ with TTB having the highest inhibitory effect of $71.05 \%$. Furthermore, all the parts of the plant studied (Fig.3) showed maximum inhibitory effect at $0.5 \mathrm{mg} / \mathrm{l}$ for the chloroform extract except for TTB that had its maximum inhibitory effect at $0.5 \mathrm{mg} / \mathrm{l}$ for the choloroform extract $(84.34 \%)$. For the Petroleum ether extracts (Fig. 4), maximum inhibitory effects were observed for TTR $(74.08 \%)$ at concentration of $0.5 \mathrm{~m} / 1$, TTB $(74.34 \%)$ at concentration of $2.0 \mathrm{mg} / 1$.; while TTL $(63.68 \%$ ) had maximum inhibitory effect at $0.5 \mathrm{mg} / \mathrm{l}$ concentration. For the Aqueous methanol extract (Fig. 5), TTB showed continuous increase in inhibitory not effects as the concentration increases; TTR had maximum inhibitory effect at $1.0 \mathrm{mg} / \mathrm{l}$, while the maximum inhibitory effect of TTL was at $0.5 \mathrm{mg} / 1$.

Moreover, the dose dependent inhibitory effects of the acetyl cholinesterase activities of the parts of the plants extracts studied were evaluated based on the different solvent used which are shown in Figs. 6-8.

Fig. 6 shows the inhibitory effects by T. tetarptera leaves using different solvents, all the solvents showed maximum inhibitory effects at $0.5 \mathrm{mg} / \mathrm{l}$ with highest value of $74.97 \%$ recorded for Aqueous methanol except for water extract that had maximum inhibitory effect at 1.0 $\mathrm{mg} / \mathrm{l}$ with a value of $70.00 \%$. For T. tetarpter a bark (Fig. 7 ), an increase in the inhibitory effect of acetyl cholinesterase as the concentration of the extracts increases were observed for Pet. ether and aqueous methanol solvents while the chloroform extract had maximum inhibitory effects at $1.0 \mathrm{mg} / \mathrm{l}$ concentration with a value of $84.34 \%$. For the T. tetraptera root (Fig. 8), maximum inhibitory effects were observed for all the solvents at $0.5 \mathrm{mg} / \mathrm{l}$ except for aqueous methanol and water with pet. ether having the highest value of $74.08 \%$, Aqueous methanol had maximum inhibitory effects at $1.0 \mathrm{mg} / \mathrm{l}$ with a value of $73.80 \%$. Both water and aqueous methanol extracts exhibited the same inhibitory effects at $0.5 \mathrm{mg} / \mathrm{l}$ concentration with a value of $59.27 \%$.

Koelle (1975) reported that for significant effect to occur in-vivo, an anti-cholinesterase agent must generally inhibit from 50-90\%. Also, several studies have reported the anti-cholinesterase activities of plant extracts (Ortega et al., 2004, Orhan et al., 2004, Viegas et al., 2005 and Raffeeq et al., 2006). Furthermore, Ahmad et al. (2003) and Raffeeq et al. (2006) in their studies of some plants extracts reported the presence of steroidal galactoside contents which may have a role in its enzyme inhibitory activity.

An increase in pest toxicity is usually accompanied by an increase in the inhibitory effect of acetyl cholinesterase activity. Cholinesterase is an enzyme that catalyses the hydrolysis of the neurotransmitter acetyl choline (Lester, 1977) into choline and acetic acid. The reaction allows cholinergic neuron to return to its resting state after activation. Anticholinesterase substances (cholinesterase inhibitors) suppress this action of the enzyme. Substances that interfere with the action of cholinesterase are potent neurotoxins causing excessive salivation and eye-watering, low doses followed by muscles spasms (sudden uncontrollable strong tightening of the muscles) and ultimately death. Anti-cholinesterase agents as a group have received more extensive application as toxic agents in the form of agricultural insecticides and potential chemical warfare.

The acetyl cholinesterase inhibitory effects of $T$. tetraptera could be attributed to its known pesticidal activity in its local applications as a insect and snake repellants (Nwaiwu and Aka, 1986, Akobundu and Agyakwa, 1998). Anti-cholinesterase substances are used as biochemical warfare in addition to its use as anesthesia or in the treatment of myasthenia gravis, glaucoma (eye disease causing gradual lost of sight) and Alzheimer's disease (a serious disease of the brain that prevents its normal function and causes loss of memory, loss of ability to speak clearly) etc.

Apart from the pesticidal activities of the plants studied, their cholinesterase properties could further be used to explore their potential in drug discovering for the treatment of the above mentioned ailments. However, a good number of plant extracts and pure components of natural origin have been reported to have anticholinesterase property (Sung et al., 2002; Ahmed et al., 2003; Ortega et al., 2004; Orhan et al., 2004; Rafeeq et al., 2006; JohnBull and Muluh, 2009).

Antimicrobial inhibition activities: The results of the anti-microbial screening of the crude extracts of parts of plants under study are shown in Table 1 . The result showed that among all the test organisms screened, the ethanol and water extracts of the leaves, stem, bark and root of T. tetraptera plants had promising activity against E. coli, S. aureus, P. mirabilis, P. aeruginosa and $K$. pneumonia bacteria and $A$. fumigatus and Rhizopus species fungi. There were no activity shown by the ethanol and water extracts of the parts of the plants with F. oxysporum, Penicillium chrysogenum and Mucor species fungi. The water and ethanol extracts of the parts 


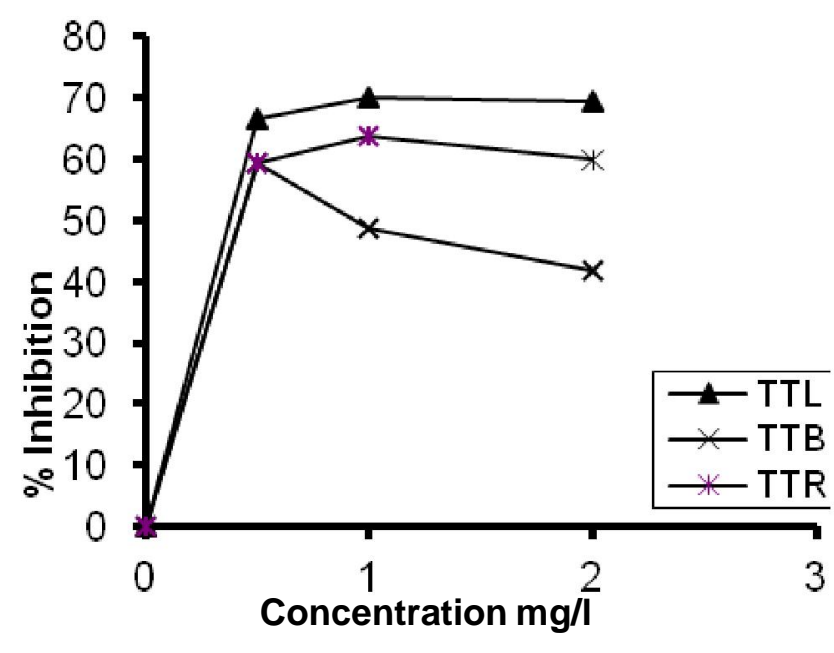

Fig. 1. D ose dependent inhibition of A cetylcholinester ase (ACHE) activity by the water extracts of the leaves, barks and root of $\mathrm{T}$. tetraptera.

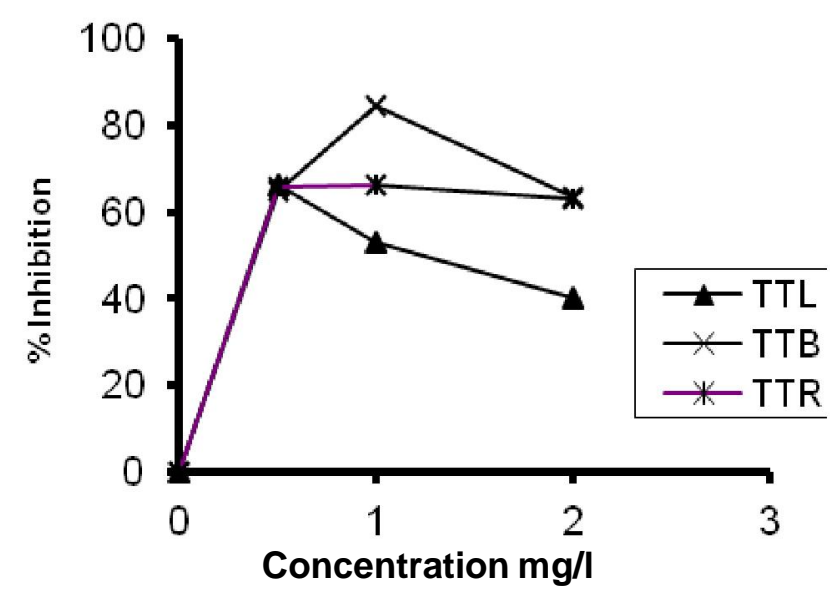

Fig. 3. D ose dependent inhibition of acetyl cholinesterase (ACHE) activity by the chloroform extracts of leaves, bark and root of $T$. tetraptera.

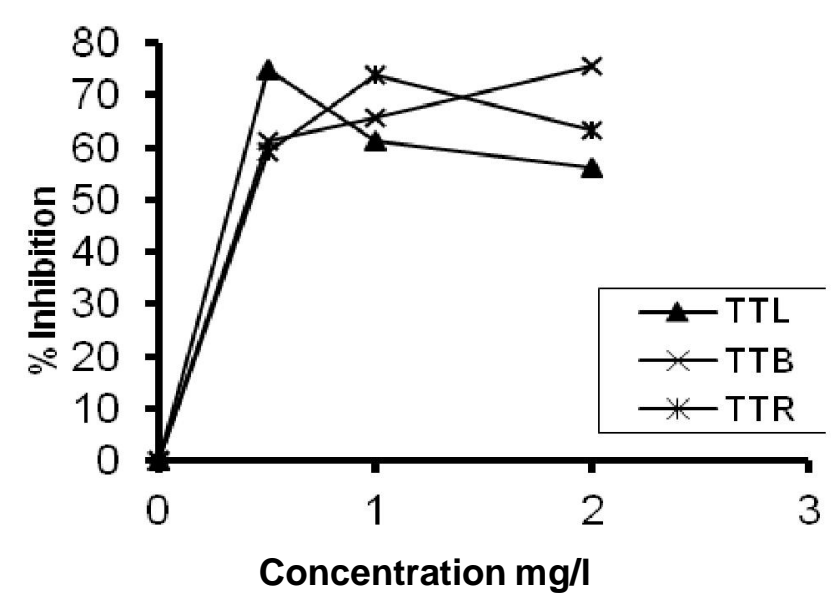

Fig. 5. D ose dependent inhibition of acetyl cholinesterase (ACHE) activity by the aquous methanol extracts of leaves, bark and root of T. tetraptera.

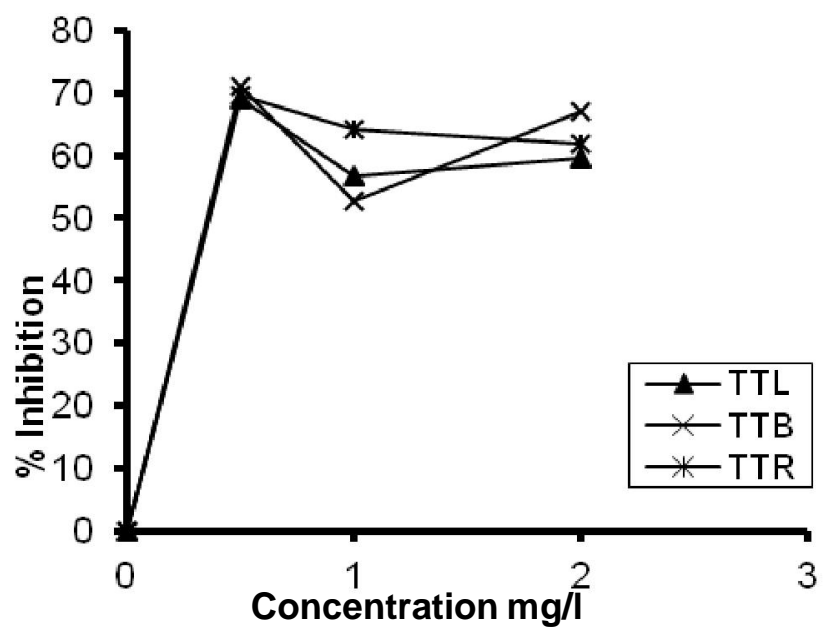

Fig. 2. D ose dependent inhibition of Acetylcholinesterase (ACHE) activity by the crude ethanol extracts of the leaves, barks and root of T. tetraptera.

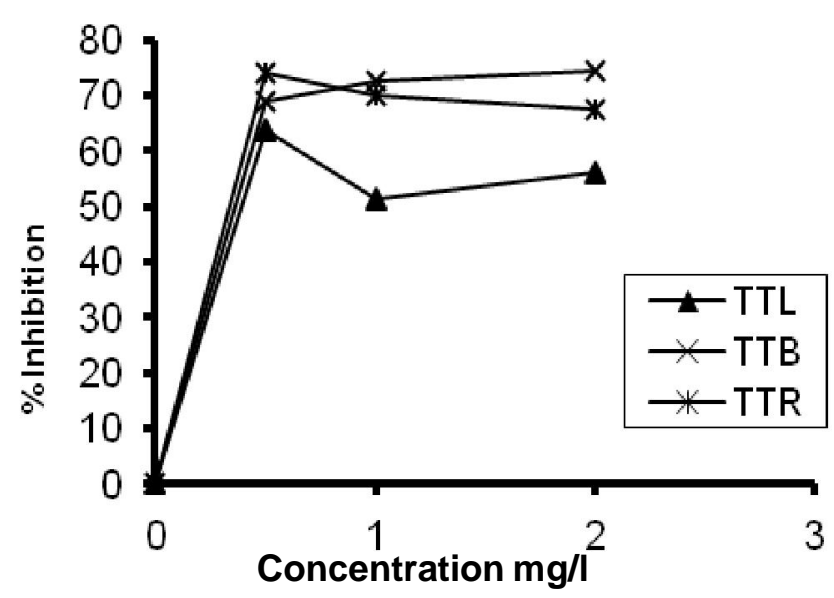

Fig. 4. D ose dependentinhibition of acetyl cholinesterase (ACHE) activity by the Pet. ether extracts of leaves, bark and root of $\mathrm{T}$. tetraptera.

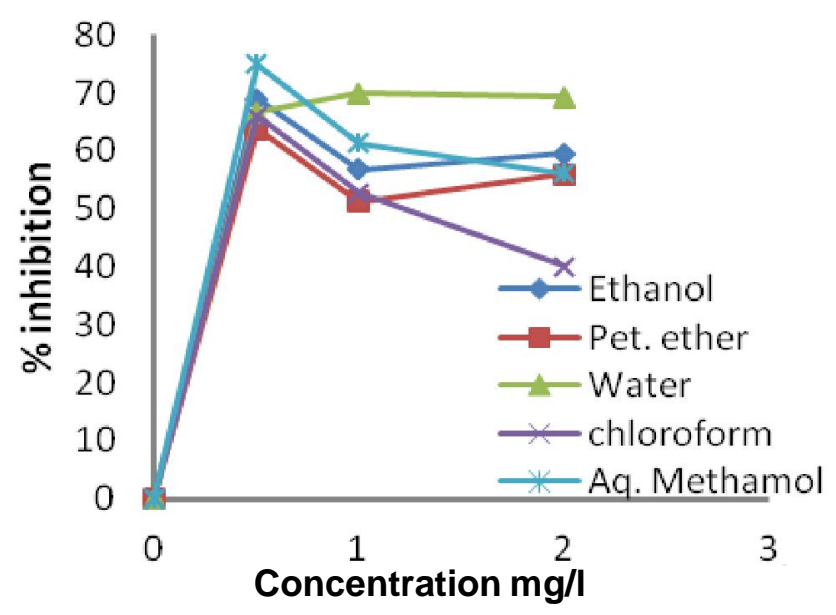

Fig. 6. D ose dependent inhibition of acetyl cholinesterase (ACHE) activity by different sol vent extracts leaves of $\mathrm{T}$. tetraptera. 
Table 1. Zone of inhibition (mm) of anti-microbial activity of the leaves, stem, bark and root of T. tetraptera plants and that of the standard.

\begin{tabular}{|c|c|c|c|c|c|c|c|c|c|}
\hline \multirow[b]{2}{*}{ Microbes } & \multirow[b]{2}{*}{$\begin{array}{l}\frac{0}{0} \\
\frac{0}{0} \\
0 \\
\frac{0}{0} \\
\hat{n}\end{array}$} & \multicolumn{2}{|c|}{ L eaves } & \multicolumn{2}{|l|}{ Stem } & \multicolumn{2}{|l|}{ Bark } & \multicolumn{2}{|l|}{ R oot } \\
\hline & & 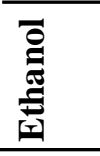 & 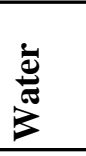 & 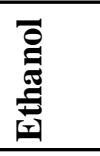 & $\frac{d}{\sqrt{0}}$ & $\begin{array}{l}\overline{0} \\
\stackrel{c}{0} \\
\stackrel{5}{ \pm} \\
\Psi \\
\end{array}$ & 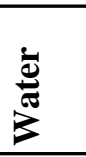 & 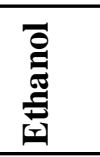 & $\frac{d}{\sqrt[0]{0}}$ \\
\hline E. coli & 20.0 & 8.0 & - & 10.0 & - & 10.0 & 10.0 & 8.0 & - \\
\hline S. aureus & 21.0 & 6.0 & - & - & 7.0 & 12.0 & - & 10.0 & 6.0 \\
\hline P. mirabilis & 19.8 & 14.0 & 18.0 & 12.0 & 10.0 & 10.0 & 5.0 & 8.0 & 8.0 \\
\hline P. aeruginosa & 17.0 & 7.0 & - & - & - & 8.5 & - & - & - \\
\hline K. pneumonia & 21.0 & - & - & - & 9.5 & - & - & 12.5 & 8.5 \\
\hline A. fumigatus & 24.0 & 16.0 & - & 8.0 & - & - & - & 7.0 & 6.0 \\
\hline F. oxysporum & - & - & - & - & - & - & - & - & - \\
\hline Penicillium chrysogenum & - & - & - & - & - & - & - & - & - \\
\hline R hizopus species & 20.0 & - & - & - & - & 11.0 & - & 12.0 & - \\
\hline Mucor species & - & - & - & - & - & - & - & - & - \\
\hline
\end{tabular}

Values are means of three replicates. Standards ciprofuxacin and benomyl solutions were used for anti-bacterial and antifungal activity assays respectively.

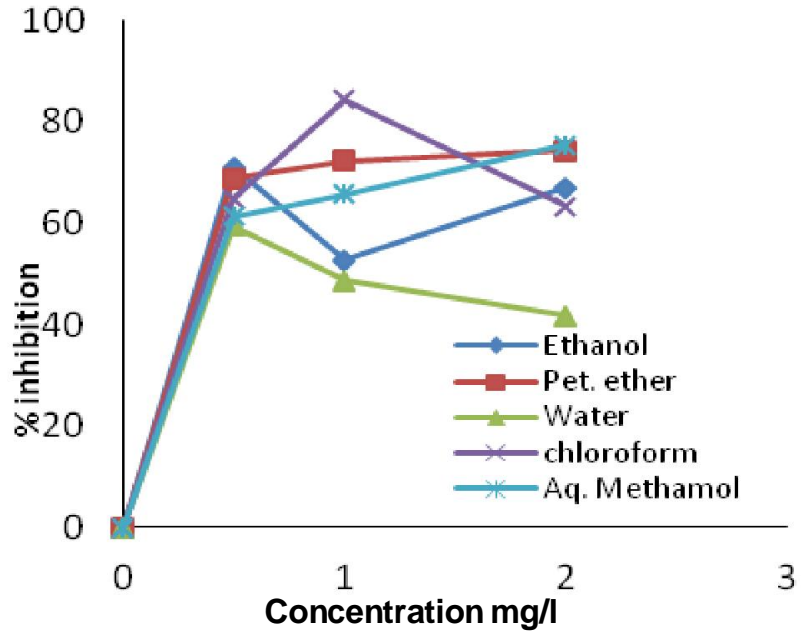

Fig. 7. D ose dependentinhibition of acetyl cholinesterase (ACHE) activity by different solvent extracts of bark of $\mathrm{T}$. tetraptera.

of the plants had activity against P. mirabilis. The bacteria strains were more sensitive to the tested extracts than the fungi strains

Table 1 shows the results of the zone of inhibition (mm) of anti-microbial activity of the leaves, stem, bark and root of $\mathrm{T}$. tetraptera plants and efficacies of the extracts relative to the standards. The ethanol extract of the leaves and water extracts of stem and roots of T. tetraptera with inhibition zones of $6.0 \mathrm{~mm}, 7.0 \mathrm{~mm}$ and $6.0 \mathrm{~mm}$ respectively antibacterial activity against $\mathrm{S}$. aureus. All the extracts exacted less activity than the standards.

Among the tested fungal strains, only A. fumigatus and Rhizopus species showed activity with $T$. tetraptera leave, stem and root. The water and ethanol extracts of the root showed the least activity against $A$. fumigatus with zones of inhibition of $6.0 \mathrm{~mm}$ and $7.0 \mathrm{~mm}$ respectively. The inhibition of ethanol extracts of bark $(11.0 \mathrm{~mm})$ and $\operatorname{root}(13.0 \mathrm{~mm})$ showed activity against $\mathrm{R}$ hizopus species.

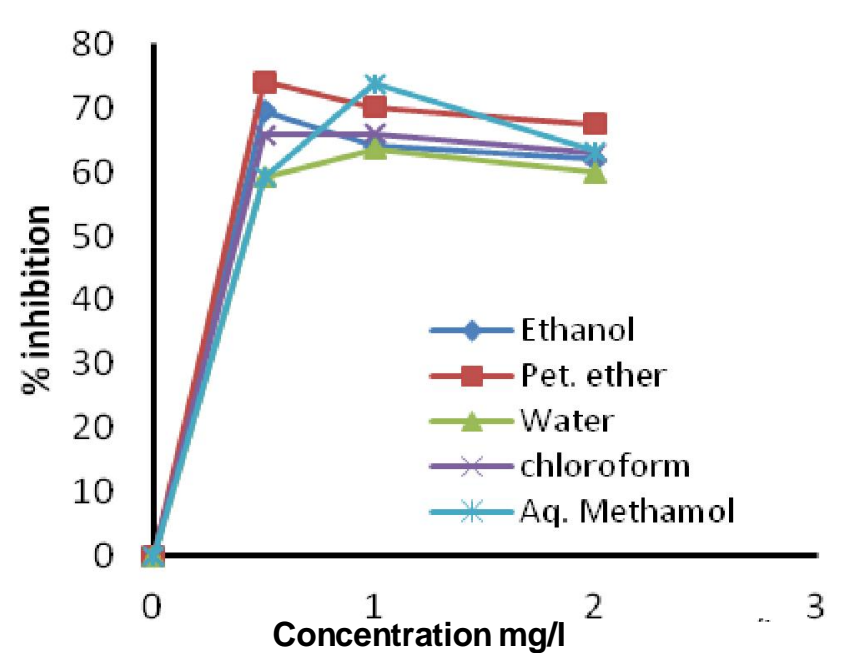

Fig. 8. D osedependentinhibition of acetyl cholinesterase (ACHE) activity by different solvent extracts of root of $\mathrm{T}$. tetraptera.

The incorporation of the ethanol extracts of these parts of the plants alongside other spectrum of fungicides materials may enhance their activity or control the destructive effects of Rhizopus species. Fungi are significant destroyers of foodstuffs and grains during storage, rendering them unfit for human consumption by retarding their nutritive value and often by producing mycotoxins (Marin et al., 1999; Janardhana et al., 1998). A significant portion of the agricultural produce becomes unfit for human consumption due to mycotoxins contamination of grains, especially those produced by species of Aspergillus (Chandra and Sarbhoy, 1997; and Janardhana et al., 1999). A. fumigatus, Rhizopus species and other organisms attack crops in the field. They have been implicated to cause blackberry disease, boll rots and seedling disease in cotton (Rajakaruna et al., 2002). Furthermore, association of variety of fungi including species of Aspergillus causing significant loss in seed 
quality and nutritional quality of grains have been reported (Koirala et al., 2005).

Furthermore, the observed in-vivo anti-bacterial and antifungal inhibitory effects by the plants parts against some selected human and plant pathogenic microorganisms studied justifies the traditional applications in disease management. T. tetraptera is used for the treatment of skin diseases, stem bark extract for the treatment of gonorrhea (Okochi et al., 1999). Both the water and ethanol extracts exhibited some level of inhibitory effects against some of the studied pathogens especially of the bacterial microorganisms which have been implicated in one bacterial infection to the other in human and plant. $\mathrm{S}$. aureus is one of the major human pathogens that could cause infections ranging from food poisoning to skin infections. E.coli and P. mirabilis cause urinary tract infections; K. pneumonia causes pneumonia. In plant Pseudominas spp causes bacterial blight in guinea corn. The antimicrobial activities of plant extracts are usually due to the activities of plant to be toxic to microorganism due to enzyme inhibition. Many plant extracts have been reported to exhibit antibacterial and antifungal activities which proved effective in the management and control of the microorganisms. Plants have these potential to control pests because they contain toxic compounds and these could be used to formulate natural control products as alternative to synthetic chemical (Cutler and Hill, 1994).

\section{Conclusion}

T. tetraptera plant showed cholinesterase and bacterial inhibitory activities. Its bacterial inhibitory activity against some of the selected pathogens showed that it could be used in the management of disease caused by such microorganisms. The findings from this research justified some of the reasons for the local use of the plant in pest control and in the management disease caused by bacterial pathogens.

\section{REFERENCES}

Adesina, S. K. (1982). Studies in Nigerian herbal Anticonvulsant recipe. International J ournal of Crude Drug. Reversed Edition Vol. 20 (2): 93-100.

Adesina, S. K., Adewunmi, C. O. and Marquis, V. O. (1980). Phytochemical investigation of the mullusicidal properties of Tetrplueura tetraptera (Taub). J ournal of African M edical Plants, 3: 7-15.

Adewunmi, C. O., Gebremedhin, G., Becker, W., Olorunmola, F. O., Dorfler, G. and Adewunmi, T. A. (1993). Schistosomiasis and intestinal parasites in rural villages in south west Nigeria: an indication for expanded programme on drug distribution and integrated control programme in Nigeria". Trop. M ed. Parasitol., 44: 177-180.

Ahmad, I., Anis, I., Malik, A., Nawaz, S. A. and Choudhary, M. I. (2003). Cholinesterase inhibitory constituents from Onosma hispida. Chem. Pharm. Bull., 51(4): 412-414

Akobundu, I. O. and Agyakwa, C. W. (1998). A Handbook of
West Africa Weeds. (2 ${ }^{\text {nd }}$ edition). International Institute of Tropical Agriculture, Ibadan. p. 418.

Bode, A. U., Adewunmi, C. O., Dorfler, G. and Becker, W. (1996). The effect of extracrs from Tetrapleura tetraptera and Baylucide on cell tissue structure of Biomuphalaria Glabrata. J ournal of Ethrophamarcology,50(2): 103.

Chandra, R. and Sarbhoy, A. K. (1997). Production of aflatoxins and zearalenone by the toxigenic fungal isolates obtained from stored food grains of commercial crops. Indian Phytopathology, 50: 458-68.

Irvine, F. R. (1961). Wooden Plants of G hana with Special Refer ences to their U ses. London: Oxford University Press. Janardhana, G. R., Raveesha, K.A. and Shetty, H.S. (1998). Modified atmosphere storage to prevent mould-induced nutritional loss in maize. Journal of Science Food and Agriculture, 76: 573-578.

Janardhana, G. R., Raveesha, K. A. and Shetty, H. S. (1999). Mycotoxin contamination of maize grains grown in Karnataka (India). F ood C hemical Toxicology, 37: 863- 868.

JohnBull, E. O. and Muluh, E. K. (2009). Phytochemical analysis and $C h E$ inhibition of Cyperus platycaulis. The Pacific J ournal of Science and Technology, 10(1): 350-356

JohnBull, E. O. and Abdu, K. (2006a). Phytochemical and antimicrobial screening of ethanol extracts of the leaves of Anogeissus leiocarpus. Biol. \& Environ. Science J. for the Tropics, 3 (3): 162-164.

JohnBull, E. O. and Abdu, K. (2006b). Screening of the extracts of Anogeissus leiocarpus for antituberculosis against: The enzyme estuation approach. A paper presented at the $20^{\text {th }}$ Annual International Conference of Chemistry Society of Nigeria on Chemistry and Global Development Environmental Concern, Lagos, September.

JohnBull, E. O. and Afolabi, S. O. (2001). Bioctive evaluation of extracts of euphorbia hirta: The anti microbial and anticholinesterase approach. J. Phytomedicine and Theapeutics, 6(2): $79-84$.

JohnBull, E. O., Ali, J., Abdulahi, S., Mustapha, A. D., Dele, R., Musa, K., Aminu, M. H. and Sylvester, M. (2001). Exploration of extracts of some Nigerian medicinal plantsThe anti microbial and anticholinesterase approach. Indian. Chem. Biol., 5: 41-45.

Keay, R. W. and Onochie, C. E. (1964). Nigerian Trees. Federal Department of Forest Research. Ibadan.

Koelle, G. B. (1975). Drugs acting at synaptic and neuro effect or functional sites. In Goodman L. S., Gilman A. (Eds.) The Pharmacological basis of therapeutics. $5^{\text {th }}$ edition. New York: Macmillian Pub. Co. Inc., 404 -476.

Koirala, P., Kumar, S., Yadar, B. K. and Premarajan, K. C. (2005). Occurrence of aflatoxin in some of the food and feed in Nepal. Indian J ournal of M edical Sciences, 59: 331-336.

Lester, H. A. (1977). The response to acetylcholine. Sci. Am., 236: 106-118.

Marin. S., Homedes, V.,Sanchis, V., Ramos, A. J. and Magan, N. (1999). Impact of F usarium moniliforme and F. prolifer atum colonisation of maize on calorific losses and fumonisin production under different environmental conditions. J ournal of Stored Product Research, 35: 15-26.

Nwaiwu, J. I. and Akah, P. A. (1986). Anticonstustant activity of the volatile oil from the fruit of Tetrapluera tetrapter $a$. J ournal of Ethnopharmacology, 8: 1-93. 
Oliver-Bever, B. (1986). Medicinal Plants of Tropical West Africa. London: Cambridge University Press.

Okochi, V. I., Gbenie, G. O., Kazeem, A. A., Fagbenro-Bayioku, A. F., Igbodudu, H. E. and Anikwe, U. (1999). Effect of water extract of Tetrapleur a tetraptera on Haematological Brucei. Nig. Q uarterly J. H ospital Med.,9 (1): 66-70.

Okwu, D. E. and Ekeke, O. (2003). Phytochemical screening and mineral composition of chewing sticks in South Eastern Nigeria. G lobal J ournal of Pure and Applied Sciences, 455-459.

Orhan, I., Sener, B., Choudhary, M. I. and Khalid, A. (2004). Acetyl cholinesterase and butrylcholinesterase inhibitory activity of some Turkish medicinal plants. J. Ethnopharmacol., 91: 57-60.

Ortega, M. G.., Agnese, A. M. and Cabrera, J.L. (2004). Anticholinesterase activity in an alkaloid extracts of $\mathrm{H}$ uperzia saururus. Phytomedicine, 11: 539-543.

Rajakaruna, N., Harris, C. S. and Towers, G. H. N. (2002). Antimicrobial activity of plants from Serpentine outcrops in Sri Lanka. Pharmaceutical Biology, 235-244.

Rafeeq, A. K., Ishfaq, A. B., Sarfraz; A. N. and Muhammad, I. C. (2006). Acetylcholinesterase and Butyrylcholinesterase inhibitory potential of some Pakistani medicinal plants. J ournal of Applied Science, 2 (1).

Sung, H. S., Kang, S. Y., Lee, K. Y., Park, M. J., Kim, J. H., Park, J. H., Kim, Y. C., Kim, J. and Kim, Y. C. (2002). (+)Vineferin, a stilbene trimer from Caragana chamlague, inhibits acteylcholinesterase. Biol.Pharm. Bull., 25(1): 125-127.

Valsaraji, R., Pushpangadan, P., Smith, U. W., Adsergen A. and Nyman, U. (1997). Antimicrobial screening of selected medicinal plants from India. J ournal of E thnopharmacology, 58: 75-83.

Viegas, C. Jr., Bolzani, V. S., Pimentel, L. S., Castro, N. G., Cabral, R. F., Costa, R. S., Floyd, C., Rocha, M. S., Young, M. C., Barreiro, E. J. and Fraga, C. A. (2005). New selective acetyl cholinesterase inhibitors designed from natural piperidine alkaloids. Bioorg M ed Chem., 13: 4184-4190. 